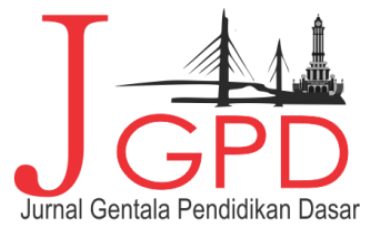

JURNAL GENTALA PENDIDIKAN DASAR Vol.3 No. I June 2018 Page 145 -162

P-ISSN : 2614-7092, E-ISSN : 2621-9611

Available Online at: http://online-journal.unja.ac.id/index.php/gentala

email : penyunting.jurnal.g-pgsd国unja.ac.id

Research Article

\title{
Penerapan Nilai Cinta Tanah Air Pada Pembelajaran Pendidikan Kewarganegaraan Di Kelas IV Sekolah Dasar
}

Irzal Anderson ${ }^{1}$, Maria Ulfa ${ }^{2}$

${ }^{1)}$ PPKN FKIP Universitas Jambi ${ }^{2)}$ PGSD FKIP Universitas Jambi, Jambi, Indonesia

\section{Article Information}

Reviewed : Feb 20, 2018

Revised : April 10, 2018

Available Online : Jun 29, 2018

Keyword

Nasionalisme, Elementary

School Students

\section{Corespondence}

e-mail :

irzal.anderson@unja.ac.id

\section{ABSTRACT}

The purpose of this study was to describe the application of the value of the love of the motherland to learning Education and citizenship in Class IV of 13 / I Muara Bulian Elementary School. The method of this research is descriptive qualitative research with the subject of grade IV teachers and students. The data in this study are obtained in 3 ways; the first by conducting observations, interviews and documentation. The results of the study show that in the application of the value of the love of the homeland carried out by the teacher to students the teacher has done it by first preparing the planning, implementation, and assessment in applying learning. So that students can carry out and show the form of the value of the love of the motherland in learning Civics. The core activities of the teacher discuss learning material about central government organizations which include the president and vice president, ministers, and the central government system. It's just that there are obstacles because of the lack of value of the love of the homeland of students towards the Indonesian people. Whereas in the attitude and fairly good assessment but in the assessment of knowledge there are still some children who have not reached the indicator so that they need more support from the teacher.

\section{DOI : https://doi.org/10.22437/gentala.v3i1.6776}

\section{PENDAHULUAN}

Pendidikan merupakan faktor yang sangat penting yang mempengaruhi sikap dan tindakan manusia dalam kehidupan, sehingga tidak heran jika kualitas suatu bangsa identik dengan kualitas pendidikannya. Pendidikan sangat berperan di dalam usaha mencerdaskan bangsa, cerdas yang dimaksud bukan hanya saja cerdas dalam emosionalnya. Maka dari itu upaya untuk mencerdaskan aspek emosional sangat diperlukan. Pendidikan adalah proses yang terus menerus dialami oleh manusia sepanjang hayat. Pendidikan mencakup segala aspek keseharian saat belajar, mengamati, mendengar, membaca, menonton, bekerja, dan lainnya. 


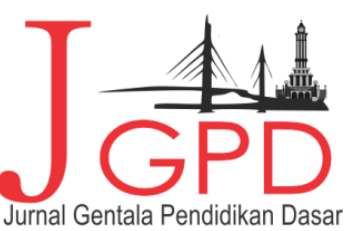

JURNAL geNTALA PENDIDIKAN DASAR Vol.3 No. I June 2018 Page 145 -162

P-ISSN : 2614-7092, E-ISSN : 2621-9611

Available Online at: http://online-journal.unja.ac.id/index.php/gentala

email : penyunting.jurnal.g-pgsd国unja.ac.id

Sebagaimana diketahui bahwa pendidikan umum dilaksanakan dalam lingkungan keluarga, sekolah, dan masyarakat.

Dengan demikian sekolah juga merupakan salah satu lembaga yang mengembangkan tugas dan tanggung jawab dalam pencapaian tujuan pendidikan bagi siswa. Sekolah juga memegang peranan yang sangat penting bagi pendidikan siswa, baik dalam mendidik hingga mendapatkan pendidikan yang layak, karena hal tersebut merupakan hal yang paling mulia dan tidak lepas dari berbagai halangan maupun tantangan, sehingga tugas guru adalah sebagai pendidik siswa di lingkungan sekolah.

Dalam dunia pendidikan, terdapat tiga aspek yang harus dikuasai oleh siswa, yaitu aspek kognitif, afektif, dan psikomotor. Aspek kognitif berorientasi pada penguasaan ilmu pengetahuan dan teknologi, aspek afektif berkaitan dengan moralitas, spirit, dan karakter sedangkan aspek psikomotor berkaitan dengan keterampilan bersifat prosedural dan cenderung mekanis. Usaha menyeimbangkan ketiga aspek tersebut memang selalu diupayakan pemerintah. Banyak usaha yang telah dilakukan pemerintah untuk mencerdaskan aspek emosional siswa dalam pendidikan di Sekolah Dasar diantaranya melalui Mata Pelajaran Pendidikan Kewarganegaraan.

Mata Pelajaran Pendidikan Kewarganegaraan merupakan mata pelajaran yang memfokuskan pada pembentukan warganegara yang memahami dan mampu melaksanakan hakhak dan kewajibannya untuk menjadi warganegara Indonesia yang cerdas, terampil, dan berkarakter yang diamanatkan oleh Pancasila dan UUD 1945 dan memahami nilai-nilai kedisiplinan, kejujuran, serta sikap yang baik terhadap sesamanya, lawan jenisnya, maupun terhadap orang yag lebih tua.

Secara bahasa, istilah Civic Education pakar diterjemahkan ke dalam bahasa Indonesia menjadi Pendidikan Kewargaan dan menjadi Pendidikan Kewarganegaraan. Dari definisi tersebut dapat di jelaskan bahwa pendidikan kewarganegaraan dirumuskan secara luas untuk mencakup proses penyiapan generasi muda untuk mengambil peran dan tanggung jawab sebagai warga negara, dan secara khusus, peran pendidikan termasuk di dalamnya persekolahan, pengajaran dan belajar, dalam proses penyiapan warga negara tersebut.

Melalui materi pendidikan kewarganegaraan juga dapat mendidik siswa agar dapat berpikir kritis, rasional, dan kreatif dalam menanggapi isu kewarganegaraan, dapat berpartisipasi 


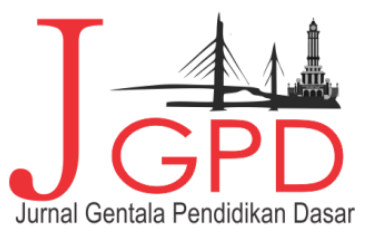

JURNAL geNTALA PENDIDIKAN DASAR Vol.3 No. I June 2018 Page 145 -162

P-ISSN : 2614-7092, E-ISSN : 2621-9611

Available Online at: http://online-journal.unja.ac.id/index.php/gentala

email : penyunting.jurnal.g-pgsd国unja.ac.id

secara aktif dan bertanggung jawab dan bertindak secara cerdas dalam kegiatan bermasyarakat, berbangsa dan bernegara, serta antikorupsi. Siswa dapat berkembang secara positif dan demokratis untuk membentuk diri berdasarkan karakter-karakter masyarakat Indonesia agar dapat hidup bersama dengan bangsa-bangsa lainnya. Sebagaimana di jelaskan dalam Susanto (2013:232) bahwa " Pendidikan kewarganegaraan juga dapat mendidik siswa agar dapat berpikir kritis, rasional, dan kreatif dalam menanggapi isu kewarganegaraan, dapat berpartisipasi secara aktif dan bertanggung jawab dan bertindak secara cerdas dalam kegiatan bermasyarakat, berbangsa dan bernegara, serta antikorupsi”. Untuk itu diperlukan pemahaman yang mendalam dan komitmen yang kuat serta konsisten terhadap prinsip dan semangat kebangsaan dalam kehidupan bermasyarakat, berbangsa, dan bernegara yang berdasarkan pada Pancasila dan Undang-Undang Dasar 1945.

Karakter perlu ditanamkan kepada seluruh siswa dalam mata Pelajaran Pendidikan Kewarganegaraan yang penting salah satunya adalah dengan penerapan nilai cinta tanah air. Penerapan nilai cinta tanah air dalam dunia pendidikan bertujuan agar siswa mempunyai pengetahuan, cara berpikir, bersikap, berbuat yang menunjukkan kesetiaan, kepedulian, dan penghargaan yang tinggi terhadap bahasa sebagaimana dijelaskan dalam Darmiatun(2013:139) bahwa "Penanaman nilai cinta tanah air dalam dunia pendidikan bertujuan agar siswa mempunyai pengetahuan, cara berpikir, bersikap, berbuat yang menunjukkan kesetiaan, kepedulian, dan penghargaan yang tinggi terhadap bahasa, lingkungan fisik, sosial, budaya, ekonomi dan politik bangsa".

Setiap siswa dapat menunjukan nilai cinta tanah air dengan cara bergaul, dan bekerja sama yang baik dengan orang lain maupun di sekitarnya dan dapat menciptakan perubahan. Nilai cinta tanah air dapat dikembangkan melalui beberapa program yang dibentuk secara khusus untuk melatih dan membiasakan siswa untuk lebih mengenal bagaimana cinta kepada tanah air. Nilai cinta tanah air tentunya menjadi dambaan institusi pendidikan dengan tindakan yang tepat diantaranya yaitu guru terlebih dahulu mengajarkan atau mencontohkan kepada siswa bagaimana tindakan sebagai warga negara Indonesia yang baik.

Copyright (c) 2018 Irzal Anderson, Maria Ulfa Attribution-NonCommercial-ShareAlike 4.0 International License 


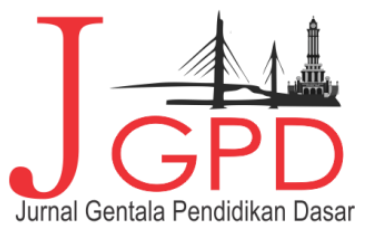

JURNAL geNTALA PENDIDIKAN DASAR Vol.3 No. I June 2018 Page 145 -162

P-ISSN : 2614-7092, E-ISSN : 2621-9611

Available Online at: http://online-journal.unja.ac.id/index.php/gentala

email : penyunting.jurnal.g-pgsd回unja.ac.id

Menyikapi hal tersebut, guru harus membiasakan siswanya menggunakan bahasa Indonesia yang baik dan benar agar tidak terkikis oleh zaman. Pembelajaran bahasa bukanlah pembelajaran verbal dengan pendekatan teoretis. Namun pembelajaran bahasa adalah pembelajaran yang menggunakan pendekatan kontekstual.

Dengan berbicara menggunakan bahasa Indonesia yang baik dan benar serta teratur, perlahan siswa akan mengikuti. Namun jika guru menjelaskan di depan kelas bagaimana cara berbahasa Indonesia yang baik namun tidak menerapkannya dalam keseharian, maka pembelajaran menjadi kurang bermakna.

Pentingnya berbahasa Indonesia yang baik dan benar didasarkan pada alasan bahwa bahasa Indonesia merupakan bahasa nasional dan bahasa persatuan yang telah disepakati sejak Sumpah Pemuda pada 28 Oktober 1928. Penggunaan bahasa nasional dalam kehidupan seharihari sudah dapat dikatakan salah satu upaya mewujudkan cinta tanah air karena secara langsung atau tidak kita telah mengajarkan kepada siswa untuk melestarikan bahasa Indonesia.

Hal sederhana lainnya adalah dengan mengajak siswa menjenguk temannya yang sakit, bersikap rukun dan saling menghormati, saling membantu jika ada temannya yang kesusahan, dan lain sebagainya. Hal-hal tersebut memang sangat sederhana, namun nilainya sangat penting. Dengan melakukan kebaikan-kebaikan kecil yang seolah tak terlihat, sebenranya pengamalan Pancasila telah dilaksanakan. Dan seperti telah dijelaskan pada bab sebelumnya, pengamalan pancasila merupakan salah satu wujud cinta kepada tanah air. Pentingnya mengamalkan Pancasila tidak hanya terjadi di lingkungan keluarga, namun juga di lingkungan sekolah, bahkan masyarakat. Pancasila sebagai ideology bangsa tentunya tidak hanya diterapkan di satu lingkungan saja, namun harus menyeluruh ke dalam setiap sendi-sendi kehidupan kita.

Upaya lainnya adalah dengan mengadakan berbagai lomba ketika menyambut perayaan hari kemerdekaan RI. Menjelang 17 Agustus, guru dapat mengadakan berbagai lomba misalnya menggambar, menari, menyanyi, tarik tambang, dan sebagainya. Manfaat dari diadakannya 


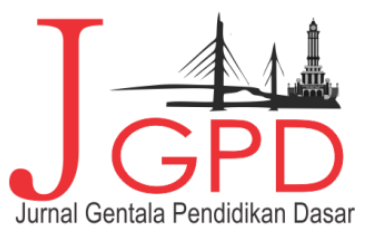

JURNAL geNTALA PENDIDIKAN DASAR Vol.3 No. I June 2018 Page 145 -162

P-ISSN : 2614-7092, E-ISSN : 2621-9611

Available Online at: http://online-journal.unja.ac.id/index.php/gentala

email : penyunting.jurnal.g-pgsd国unja.ac.id

lomba ini sangat banyak, antara lain mengembangkan kreativitas siswa, melatih kekompakan baik antar siswa, antar guru, maupun antara siswa dengan guru.

Kenyataanya, berdasarkan hasil wawancara dan observasi awal peneliti dengan wali kelas IV SD Negeri 13/1 Muara Bulian, peneliti menemukan bahwa siswa kelas IV SD Negeri 13/1 Muara Bulian masih banyak yang belum bisa memahami nilai cinta tanah air di kelasnya. Seperti pada pembelajaran mengenai organisasi pemerintahan pusat. Dimana masih banyak siswa yang belum tau nama presiden yang sekarang dan sebelumnya, siswa belum tau strukur organisasi pemerintahan, dan jabatan lainya. Sehingga guru perlu memberikan pemahaman lebih lanjut agar siswa dapat mengetahui serta dapat menerapkan rasa cinta tanah air diantaranya pada pembelajaran mengenai organisasi pemerintahan pusat.

Berdasarkan latar belakang masalah diatas, Penulis tertarik untuk melakukan penelitian lanjut yaitu tentang "Penerapan Nilai Cinta Tanah Air Pada Pembelajaran PKn di Kelas IV SD Negeri 13/1 Muara Bulian".

Sebelum melakukan penelitian ini, peneliti telah menelusuri beberapa hasil penelitian terdahulu yang memiliki keterkaitan dengan peneliti yang penelitilakukan ini. Beberapa penelitian yang relevan dengan penelitian ini akan dijelaskan sebagai berikut:

1. Skripsi yang berjudul "Penanaman Nilai-Nilai Cinta Tanah Air Pada Siswa Melalui Pembelajaran Pendidikan Kewarganegaraan Di Smk Negeri 1 Banyudono Kabupaten Boyolali Tahun Ajaran 2012/2013" atas nama Utami (2013) dengan menggunakan metode penelitian kualitatif. Tujuan penelitian ini adalah untuk mendeskripsikan kendalakendala penanaman nilai-nilai cinta tanah air pada siswa melalui pembelajaran pendidikan kewarganegaraan di SMK Negeri 1 Banyudono Tahun Ajaran 2012/2013 dan Hasil penelitian ini menunjukkan strategi penanaman nilai -nilai cinta tanah air telah di lakukan dengan baik oleh guru PKn Dengan cara penyusunan perencanaan pembelajaran yang di dalamnya terdapat nilai-nilai yang mencerminkan cinta tanah air pada siswa. Dalam pelaksanaan pembelajaran telah melakukan penanaman nilai-nilai cinta tanah air dengan cara presentasi di awal pembelajaran, menyanyikan lagu nasional, menjaga kebersihan dan ketertiban kelas untuk menjadikan suasana belajar yang tenang dan 


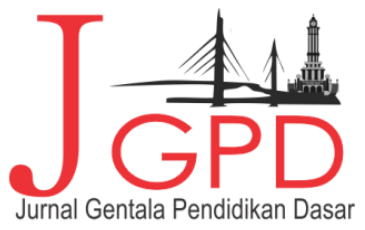

JURNAL geNTALA PENDIDIKAN DASAR Vol.3 No. I June 2018 Page 145 -162

P-ISSN : 2614-7092, E-ISSN : 2621-9611

Available Online at: http://online-journal.unja.ac.id/index.php/gentala

email : penyunting.jurnal.g-pgsd国unja.ac.id

nyaman, studi ke hutan yang ada untuk belajar dan memahami cinta tanah air dalam bentuk peduli terhadap rusaknya lingkungan atau hutan, menjaga kerahasiaan soal-soal ujian. Kendala penanaman nilai melalui pembelajaran PKn baik berasal dari diri Guru. Kepala sekolah maupun siswa. Kendala yang ada yang lebih sering dihadapi adalah kesulitan Guru dan tidak sadarnya siswa akan pentingnya cinta tanah air.

2. Skripsi yang berjudul " Penanaman nilai cinta tanah air melalui pembelajaran PKn di SD Negeri 148/1 Kilangan 1, atas nama Lestari (2014) dengan menggunakan metode Kualitatif. Tujuan penelitian ini adalah untuk mengetahui tentang kekayaan alam dan budaya Indonesia, menggunakan bahasa yang baik dan tidak menggunakan bahasa deerah, dengan tujuan siswa lebih mencintai nilai cinta tanah air. Hasil penelitian ini menyimpulkan bahwa siswa dapat mengetahui tentang kekayaan alam dan budaya Indonesia dengan menggunakan bahasa yang baik dan tidak menggunakan bahasa daerah.

Dari beberapa judul kajian penelitian yang relevan seperti dijelaskan diatas, maka terdapat perbedaan objek yang teliti meskipun sama-sama menjelaskan tentang pengaruh metode dan model pembelajaran tertentu terhadap hasil belajar siswa. Judul skripsi yang saya pilih yaitu menjelaskan penerapan nilai cinta tanah air pada pembelajaran kelas IV SD Negeri 13/1 Muara Bulian. Menggunakan metode penelitian yang sama yaitu metode kualitatif dengan tujuan untuk mengetahui penerapan cinta tanah air pada pembelajaran PKn di kelas 4 SDN N13/1 Muara Bulian.

\section{METODE PENELITIAN}

\section{Pendekatan Penelitian}

Penelitian ini menggunakan pendekatan kualitatif, yaitu penelitian yang hasilnya berupa data deskriptif melalui fakta-fakta dari kondisi alami sebagai sumber langsung dengan instrumen dari peneliti sendiri.

Menurut Sugiyono (2014: 4) Penelitian kualitatif adalah penelitian yang bermaksud untuk memahami fenomena tentang apa yang dialami oleh subjek penelitian, misalnya perilaku, persepsi, motivasi, tindakan, dan lain lain.secara holistik, dan dengan cara deskripsi dalam 


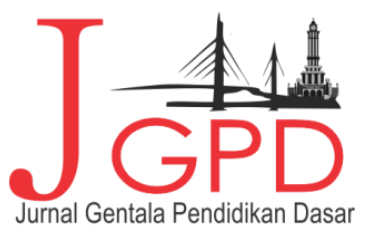

JURNAL geNTALA PENDIDIKAN DASAR Vol.3 No. I June 2018 Page 145 -162

P-ISSN : 2614-7092, E-ISSN : 2621-9611

Available Online at: http://online-journal.unja.ac.id/index.php/gentala

email : penyunting.jurnal.g-pgsd回unja.ac.id

bentuk kata-kata dan bahasa, pada suatu konteks khusus yang alamiah dan dengan memanfaatkan berbagai metode alamiah.

Sedangkan Menurut Mukhtar (2013:29) "deskriptif kualitatif adalah penelitian yang dimaksudkan untuk mengungkapkan sebuah fakta empiris secara objektif ilmiah dengan berlandaskan pada logika keilmuan, prosedur dan didukung oleh metodeologi dan teoritis yang kuat sesuai disiplin keilmuan yang ditekuni”. Dengan demikian penelitian deskriptif dapat dikatakan sebagai penelitian yang bertujuan mengungkap semua fakta secara objektif tentang masalah-masalah sosial yang terjadi.

Tujuan utama dilakukannya penelitian deskriptif adalah menggambarkan secara sistematis fakta dan karakteristik objek atau subjek yang diteliti secara tepat.Peneliti tidak memberikan perlakuan-perlakuan tertentu terhadap variabel atau merancang sesuatu yang diharapkan terjadi pada variabel, tetapi seluruhkegiatan, keadaan, kejadian, aspek, komponen, atau variabel berjalan sebagaimana adanya. Penelitian ini bertujuan untuk mendeskripsikan suatu keadaan, melukiskan dan menggambarkan penerapan nilai cinta tanah air pada siswa melalui pembelajaran PKn di kelas IV SD Negeri 13/I Muara Bulian.

\section{Subjek Penelitian}

Menurut Mukhtar (2013:89) "subjek penelitian adalah orang yang berada dalam situasi sosial yang ditetapkan sebagai pemberi informasi dalam sebuah penelitian atau dikenal dengan informan". Adapun subjek dalam penelitian ini adalah guru kelas IV dan siswa kelas IV SD Negeri13/1 Muara Bulian.

\section{Tempat dan Waktu Penelitian}

Penelitian ini dilakukan di SD Negeri13/I Muara Bulian, SD Negeri 13/I Muara Bulian yang berlokasi di daerah kecamatan Muara Bulian, Kabupaten Batang Hari. Adapun mengenai pelaksanaan penelitian dilakukan pada semester genap tahun ajaran 2016

\section{Kehadiran Peneliti}




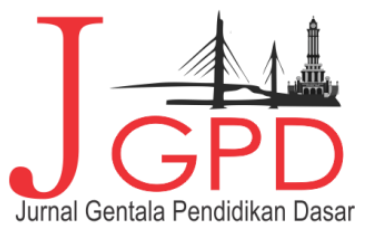

JURNAL geNTALA PENDIDIKAN DASAR Vol.3 No. I June 2018 Page 145 -162

P-ISSN : 2614-7092, E-ISSN : 2621-9611

Available Online at: http://online-journal.unja.ac.id/index.php/gentala

email : penyunting.jurnal.g-pgsd国unja.ac.id

Kehadiran peneliti dalam penelitian kualitatif mutlak diperlukan, karena peneliti sendiri merupakan alat (instrumen) pengumpul data yang utama sehingga kehadiran peneliti mutlak diperlukan dalam menguraikan data nantinya. Karena dengan terjun langsung ke lapangan maka peneliti dapat melihat secara langsung fenomena di daerah lapangan. Menurut Moleong (2010:168) "kedudukan peneliti dalam penelitian kualitatif cukup rumit". Karena dalam penelitian kualitatif ini Ia sekaligus merupakan perencana, pelaksana pengumpulan data, analisis, penafsiran data, dan pada akhirnya ia menjadi pelapor hasil penelitiannya. Kedudukan peneliti sebagai instrumen atau alat peneliti ini sangat tepat, karena ia sangat berperan segalanya dalam proses penelitian.

Sedangkan kehadiran peneliti dalam penelitian ini diketahui statusnya sebagai peneliti oleh subjek atau informan, dengan terlebih dahulu mengajukan surat izin penelitian kelembaga yang terkait. Adapun peran peneliti dalam penelitian ini adalah sebagai pengamat berperan serta yaitu peneliti tidak sepenuhnya sebagai pemeran serta tetapi masih melakukan fungsi pengamatan. Peneliti disini pada waktu penelitian mengadakan pengamatan langsung, sehingga diketahui fenomena-fenomena yang terlihat.

\section{Data Penelitian}

Data dalam penelitian ini bersifat deskriptif karena ingin melihat penerapan nilai cinta tanah pada pesetra didik. Data dalam penelitian ini berupa transkip wawancara dengan guru dan siswa, hasil observasi selama proses penelitian dan dokumentasi.

\section{Sumber Data Penelitian}

Dari pengertian tersebut, maka yang menjadi sumber data dalam penelitian ini adalah guru kelas IV di SD Negeri 13/1 Muara Bulian.

\section{Teknik Pengumpulan Data}

Sugiyono (2014: 137-145) mengemukakan bahwa teknik pengumpulan data merupakan langkah yang paling strategis dalam penelitian, karena tujuan utama dari penelitian adalah mendapatkan data. Pengumpulan data dalam penelitian kualitatif dilakukan pada kondisi yang alamiah (natural setting), sumber data primer, dan teknik pengumpulan data lebih banyak pada 


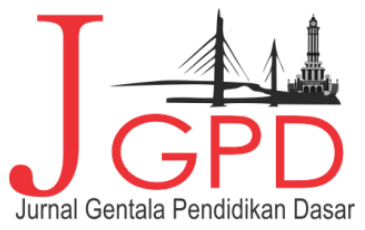

JURNAL GENTALA PENDIDIKAN DASAR Vol.3 No. I June 2018 Page 145-162

P-ISSN : 2614-7092, E-ISSN : 2621-966II

Available Dnline at: http://online-journal.unja.ac.id/index.php/gentala

email : penyunting.jurnal.g-pgsd回unja.ac.id

observasi, wawancara mendalam dan dokumentasi. Teknik pengumpulan data yang dilakukan dalam penelitian ini adalah sebagai berikut.

\section{Observasi}

Sugiyono, (2014: 145) menyatakan bahwa, observasi adalah suatu proses yang kompleks, yang tersusun dari berbagai proses biologis dan psikologis. Dua hal yang penting dalam observasi yaitu proses pengamatan dan ingatan. Observasi dalam penelitian ini dilakukan saat pembelajaran. Observasi yang digunakan ialah observasi non partisipan. Peneliti tidak langsung terlibat dan hanya sebagai pengamat independen. Peneliti mencatat, menganalisis, dan membuat kesimpulan tentang penerapan nilai cinta tanah air pada pembelajaran PKn di Kelas IV SD Negeri 13/I Muara Bulian.

Adapun kegiatan observasi dalam penelitian ini adalah dengan menyiapkan lembar observasi. Dalam hal ini peneliti hanya mengamati perencanaan, pelaksanaan, dan evaluasi yang dilaksanakan guru, bukan ikut dalam melaksanakan proses pembelajaran dan tetap melakukan kegiatan observasi dengan mencatat semua apa yang dilihat. Adapun lembar observasi sebagai berikut.

Tabel 1. Kisi-kisi nila cinta tanah air pada pembelajaran PKn kelas IV SD Negeri 13/1 Muara Bulian

\begin{tabular}{lll}
\hline $\begin{array}{l}\text { Standar } \\
\text { kompetensi }\end{array}$ & $\begin{array}{l}\text { Kompetensi } \\
\text { dasar }\end{array}$ & Indikator \\
\hline 4.Mengenal & 4.2 & -Memahami \\
pemerintahan & Menyebutkan & lembaga \\
tingkat pusat & organisai & eksekutif \\
& pemerintahan & (presiden \\
& pusat, seperti & \\
& presiden, wakil & \\
& presiden dan & \\
& para menteri. & \\
\hline
\end{tabular}

Copyright (c) 2018 Irzal Anderson, Maria Ulfa Attribution-NonCommercial-ShareAlike 4.0 International License 153 | P a g e 


\section{Wawancara}

Sugiyono (2014:137) mendefinisikan wawancara sebagai suatu percakapan dengan maksud tertentu yang dilakukan oleh dua pihak yaitu pewawancara yang mengajukan pertanyaan dan terwawancara yang memberikan jawaban atas pertanyaan tersebut. Penelitian ini menggunakan wawancara semiterstruktur dalam pelaksanaan pengumpulan data di lapangan, dengan alasan jenis wawancara ini tergolong dalam kategori in-dept interview, dimana dalam pelaksanaannya lebih bebas bila dibandingkan dengan wawancara terstruktur. Jenis wawancara ini bertujuan menemukan permasalahan secara lebih terbuka sehingga peneliti dapat menambah pertanyaan di luar pedoman wawancara untuk mengungkap pendapat dan ide-ide dari responden.

Menurut Mukhtar (2013:118) "wawancara adalah proses tanya jawab antara peneliti dengan subjek penelitian atau informan dalam satu situasi sosial". Metode wawancara adalah percakapan dengan maksud tertentu. Percakapan itu dilakukan oleh dua pihak, yaitu pewawancara yang mengajukan pertanyaan dan terwawancara yang memberi jawaban atas pertanyaan itu. Data yang diperoleh dengan wawancara ini mengenai informasi tentang hal-hal yang berkenaan dengan nilai cinta tanah air dan juga faktor pendukung dan penghambat dalam penerapan nilai cinta tanah air.

Untuk memperoleh data yang diinginkan, peneliti menggunakan pedoman wawancara sebagai berikut:

Tabel 2. Panduan wawancara terhadap guru kelas IV SD Negeri 13/1 Muara Bulian

\begin{tabular}{cl}
\hline No & \multicolumn{1}{c}{ Pertanyaan untuk wali kelas } \\
\hline 1 & Bagaimana langkah-langkah perencanaan yang Ibu buat sebelum melaksanakan \\
& penerapan nilai cinta tanah air pada pembelajaran PKn di dalam kelas \\
\hline 2 & $\begin{array}{l}\text { Bagaimana proses pelaksanaan yang ibu lakukan dalam melaksanakan pembelajaran } \\
\text { nilai cinta tanah air pada pembelajaran PKn di dalam kelas ? }\end{array}$ \\
\hline 3 & Bagaimana hasil penilaian dari hasil kerja siswa, apakah sesui dengan konsep yang Ibu \\
& rancang \\
\hline 4 & Apakah yang menjadi kendala Ibu dalam melaksanakan penerapan nilai cinta tanah air \\
\hline
\end{tabular}




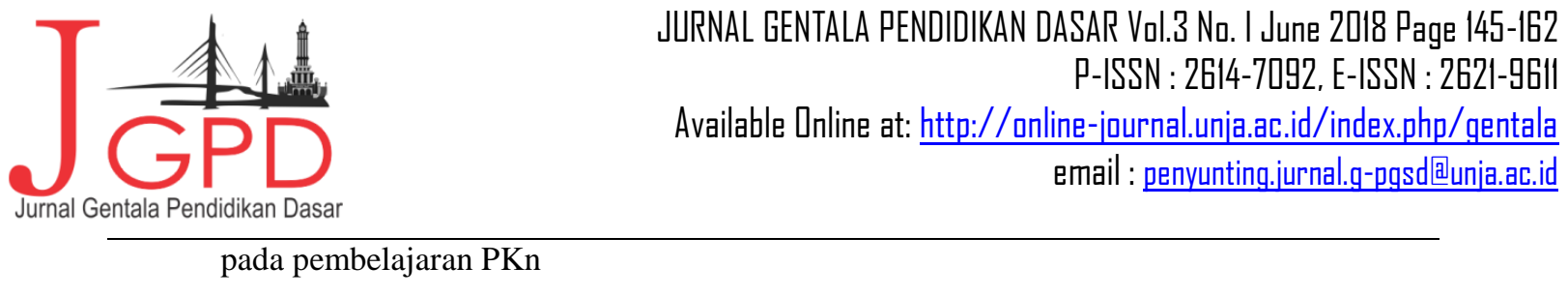

\section{Dokumentasi}

Suharsimi Arikunto (2010: 274) mengemukakan bahwa metode dokumentasi yaitu mencari data mengenai hal-hal atau variabel yang berupa catatan, transkrip, buku, surat kabar, majalah, prasasti, notulen rapat, lengger, agenda, dan sebagainya. Dokumentasi dalam penelitian ini ialah berupa RPP, lembar penilaian mata pelajaran PKn dan peneliti juga mengambil dokumentasi berupa foto yang berkaitan.

\section{Teknik Analisis Data}

Miles dan Huberman (Sugiyono, 2014: 243) mengemukakan bahwa aktivitas dalam analisis data kualitatif dilakukan secara interaktif dan berlangsung secara terus menerus sampai tuntas, sehingga datanya sudah jenuh. Peneliti menggunakan analisis data model Miles dan Huberman yang meliputi tiga tahapan, yakni reduksi data, display data, dan penarikan kesimpulan.

\section{Reduksi data}

Sugiyono (2009:338) menjelaskan bahwa mereduksi data berarti merangkum, memilih hal-hal pokok, memfokuskan pada hal-hal yang penting, dicari tema dan polanya dan membuang yang tidak perlu. Selama masa pengumpulan data, peneliti melakukan pengumpulan data-data dari hasil observasi, wawancara,dan dokumentasi. Data yang telah dikumpulkan kemudian dipilah sesuai dengan kategori masing-masing agar lebih rinci dan mudah diolah. Peneliti memilah-milah data yang berupa pemahaman guru PKn tentang nilai cinta tanah air, persiapan guru PKn sebelum memulai pembelajaran, evaluasi nilai cinta tanah air dalam pembelajaran $\mathrm{PKn}$, faktor pendorong dan penghambat penerapan cinta tanah air dalam pembelajaran PKn, serta hasil observasi proses penerapan nilai cinta tanah air dalam pembelajaran PKn. Data yang diperoleh tersebut merupakan data yang masih kompleks. Kemudian peneliti melakukan reduksi data dengan cara mengambil yang pokok dan penting, serta membuang data yang dianggap tidak diperlukan, misalnya saat wawancara dengan guru PKn. Atau siswa ada jawaban yang tidak sesuai dengan apa yang diharapkan seperti dalam pedoman wawancara, maka jawaban itu tidak 


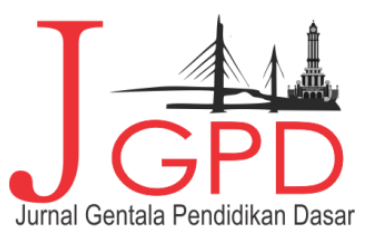

JURNAL geNTALA PENDIDIKAN DASAR Vol.3 No. I June 2018 Page 145-162

P-ISSN : 2614-7092, E-ISSN : 2621-9611

Available Online at: http://online-journal.unja.ac.id/index.php/gentala

email : penyunting.jurnal.g-pgsd国unja.ac.id

dipakai. Kemudian apabila jawaban dariguru atau siwa terlalu luas maka akan diambil inti dari jawaban tersebut saja.

\section{Display data}

Sugiyono (2009: 341) mengemukakan bahwa dalam melakukan display data, dapat disajikan dalam bentuk uraian singkat, flowchart, bagan, dan sejenisnya. Peneliti menyajikan data yang berupapersiapan guru PKn sebelum memulai pembelajaran, proses penerapan nilai cinta tanah air dalam pembelajaran. Cinta tanah air dalam pembelajaran PKn, serta faktor pendorong dan penghambat penerapan cinta tanah air dalam pembelajaran PKn. Dalam penelitian ini, data tersebut disajikan secara deskriptif.

3. Penarikan kesimpulan

Penarikan kesimpulan sering juga disebut tahap verifikasi.Tahap ini merupakan tahap terakhir dalam analisis data. Data-data mengenai pemahaman guru PKn tentang nilai cinta tanah air,proses penerapan pendidikan karakter dalam pembelajaran PKn yang berkaitan dengan nilai disiplin dan tanggung jawab, evaluasi pendidikan karakter dalam pembelajaran PKn, serta faktor pendorong dan penghambat penerapan cinta tanah air dalam pembelajaran PKn yang telah dikemukakan pada penyajian data diinterpretasikan kemudian dianalisis untuk memperoleh kesimpulan.

\section{Keabsahan Data}

Menurut Sugiyono (2009: 366) uji keabsahan data pada penelitiaan kualitatif dilakukan melalui uji credibility (validitas internal), transferability (validitas eksternal), dependability (reliabilitas), dan confirmability (objektifitas). Penelitian ini menggunakan uji kredibilitas untuk menguji keabsahan data.

Sugiyono (2009: 368) menjelaskan bahwa uji kredibilitas data atau kepercayaan terhadap data hasil penelitian kualitatif antara lain dilakukan dengan perpanjangan pengamatan, peningkatan ketekunan dalam penelitian, triangulasi, diskusi dengan teman sejawat, analisis kasus negatif, dan membercheck. Pengujian kredibilitas dalam penelitian ini digunakan triangulasi, perpanjangan pengamatan, dan member check. 


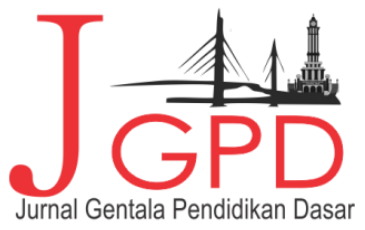

JURNAL geNTALA PENDIDIKAN DASAR Vol.3 No. I June 2018 Page 145 -162

P-ISSN : 2614-7092, E-ISSN : 2621-9611

Available Online at: http://online-journal.unja.ac.id/index.php/gentala

email : penyunting.jurnal.g-pgsd回unja.ac.id

Triangulasi yang digunakan meliputi triangulasi sumber dan triangulasi teknik. Triangulasi sumber dilakukan peneliti dengan menggali informasi dari kepala sekolah lalu triangulasi ke guru serta melebar ke siswa. Data dari sumber-sumber tersebut dideskripsikan, dikategorisasikan, mana yang memiliki pandangan sama, yang berbeda, dan mana yang spesifik. Sedangkan triangulasi teknik dilakukan dengan membandingkan data hasil observasi, wawancara, dan dokumentasi dari sumber yang sama yaitu guru PKn. Jika hasil kroscek ketiganya saling terkait maka data dapat dipercaya kebenarannya. Kemudian peneliti juga melakukan perpanjangan pengamatan yakni peneliti tidak hanya mengobservasi kegiatan cinta tanah air saja. Peneliti juga menggunakan member check dengan melakukan pengecekan data yang diperoleh disepakati oleh pemberi data, maka data tersebut valid.

\section{HASIL DAN PEMBAHASAN}

\section{Hasil}

\section{Paparan Data}

Hasil penelitian dari tanggal 03 Mei sampai dengan 03 Juni 2016 yang ditemui peneliti tentang penerapan nilai cinta tanah air pada pembelajaran PKn SD Negeri 13/1 Muara Bulian. Didalam menemukan hasil penelitian penerapan nilai cinta tanah air pada pembelajaran PKn ada 3 (tiga) instrumen yang digunakan yaitu lembar observasi, panduan wawancara, dan dokumentasi.

\section{Penerapan Nilai Cinta Tanah Air Pada pembelajaran PKn}

Hasil penelitian ini dapat diuraikan berdasarkan data yang akan menjawab rumusan masalah penelitian. Data penelitian diperoleh melaui observasi, wawancara dan dokumentasi yang dilakukan oleh peneliti. Kemudian data penelitian tersebut dianalisis sehingga memperoleh kesimpulan yang akan menjawab rumusan masalah penelitian. Ada tiga tahap-tahap penerapan nilai cinta tanah air pada pembelajaran PKn yang peneliti observasi adalah sebagai berikut:

\section{Perencanaan Pembelajaran PKn}

Kegiatan observasi peneliti dilakukan pada tanggal 05 Mei 2016 menerangkan bahwa : Pada tahap perencanaan guru merancang dan menyiapkan Rencana Pelaksanaan Pembelajaran (RPP). Dalam merancang RPP yang pertama kali dulakukan oleh guru yakni melihat standar 


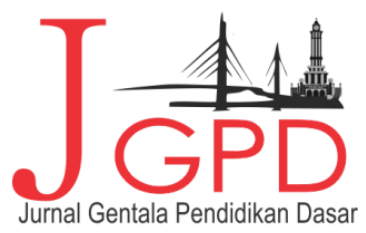

JURNAL geNTALA PENDIDIKAN DASAR Vol.3 No. I June 2018 Page 145 -162

P-ISSN : 2614-7092, E-ISSN : 2621-9611

Available Online at: http://online-journal.unja.ac.id/index.php/gentala

email : penyunting.jurnal.g-pgsd国unja.ac.id

kompetensi dan kompetensi dasar. Kemudian guru merumuskan indikator pembelajaran sesui dengan standar kompetensi dan kompetensi dasar. Yang keduan guru menentukan tujuan pembelajaran sesui dengan indikator yang telah dibuat oleh guru. Yang ketiga guru menyiapkan materi yang akan diajarkan kepada siswa sesui dengan tujuan pembelajaran. Pada proses pelaksanaan pembelajaran guru menggunakan metode ceramah,membuat penilaian kepada siswa berdasarkan materi yang diajarkan beserta dan memuat proses pembelajaran di dalam kelas berupa gambar.

Berdasarkan hasil observasi dapat peneliti simpulkan bahwa pada tahap perencanaan guru menyiapkan RPP, bahan ajar sesui dengan standar kompetensi dan kompetensi dasar.

Berdasarkan hasil wawancara peneliti dengan Ibu Neti S.Pd selaku guru kelas IV SD Negeri 13/1 Muara Bulian pada tanggal 03 Mei 2016 mengenai langkah-langkah perencanaan yang Ibu buat sebelum melaksanakan penerapan nilai cinta tanah air pada pembelajaran PKn di dalam kelas, mengatakan bahwa:

"Perencanaan yang saya buat sebelum melaksanakan pembelajaran dimulai dari membuat Rencana Pelaksanaan Pembelajaran (RPP) sebelum memulai proses belajar mengajar, mempelajari materi terlebih dahulu sebelum mengajar, menyampaikan proses pembelajaran sesui dengan apa yang ada di dalam buku.

Dan menggunakan media gambar saat proses pembelajaran"

Sehingga dapat diambil kesimpulan perencanaan yang dirancang oleh guru sebelum melaksanakan pembelajaran nilai cinta tanah air pada pembelajaran PKn membuat RPP, membaca materi terlebih dahulu sebelum mengajar dan menggunakan media gambar .

\section{Pelaksanaan pembelajaran PKn}

Kegiatan observasi yang dilakukan peneliti pada tanggal 05 Mei 2016 menerangkan bahwa : Pada tahap pelaksanaa guru memulai pembelajaran dengan berdoa, mengabsen siswa, mengajak siswa menyayikan lagu indonesia raya, sebelum memasuk ke pelajaran berikutnya guru mengaitkan kembali mengenai pembelajaran yang telah dipelajari sebelumnya. Kemudian pada proses inti guru siswa membuka buku paket tentang organisasi pemerintahan pusat halaman 61, guru terlebih dahulu menyampaikan materi dan siswa memperhatikan guru, di situ tampak 


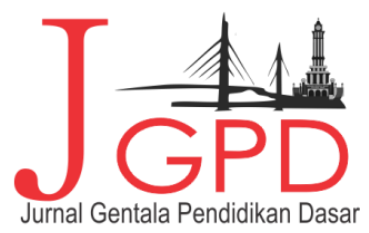

JURNAL geNTALA PENDIDIKAN DASAR Vol.3 No. I June 2018 Page 145 -162

P-ISSN : 2614-7092, E-ISSN : 2621-9611

Available Online at: http://online-journal.unja.ac.id/index.php/gentala

email : penyunting.jurnal.g-pgsd国unja.ac.id

guru menjelaskan materi "organisasi pemerintahan pusat" yang membahas tentang presiden dan wakil presiden di Indonesia dari yang pertama sampai dengan yang menjabat pada saat ini, menteri-menteri dan sistem pemerintahan pusat. Guru juga memperlihatkan kepada siswa foto presisen dan wakil presiden.

Pada proses pelaksanaan guru menggunakan metede ceramah karena materi lebih banyak cerita. Guru juga memamfaatkan media selain dari buku paket seperti media gambar mengenai foto presiden dan wakil presiden. Kemudian guru melakukan penilaian dari pemahaman dan pengetahuan siswa dengan materi yang telah guru jelaskan dari individu siswa. Dan setelah materi selesai guru memberikan siswa tugasa dan guru bersama siswa sama-sama meyimpulkan pembelajaran hari itu.

Berdasarkan hasil observasi dapat peneliti simpulkan bahwa pada tahap pelaksanaan dilakukan sesui dengan perencanaan yang dibuat oleh guru tampak guru menyampaikan materi.

Hasil wawancara peneliti dengan Ibu Neti S.Pd selaku guru kelas IV SD Negeri 13/1 Muara Bulian pada tanggal 03 Mei 2016 mengenai proses pelaksanaan yang ibu lakukan dalam melaksanakan pembelajaran nilai cinta tanah air pada pembelajaran PKn di dalam kelas, mengatakan bahwa:

"Pelaksanaan yang saya lakukan sesui dengan Rencana Pelaksanaan Pembelajaran (RPP), mulai dari tahap awal pembukaan berdoa bersama, mengabsen siswa, menyanyikan lagu indonesia raya, mengingat pembelajaran sebelumnya dan mengajak siswa menyimpulkan materi yang yang di pelajari dan memberikan tugas kepada siswa"

Sehingga dapat diambil kesimpulan bahawa proses pelaksanaan pembelajaran dilaksanakan sesui dengan Rencana Pelaksanaan Pembelajaran (RPP), mulai dari tahap pembukaan pembelajaran sampai tahap penutup.

\section{Penilaian}

Kegiatan observasi yang dilakukan peneliti pada tanggal 03 Mei 2016 menerangkan bahwa : Pada tahap penilaian guru melakukan penilaian berdasarkan penilaian kerja seperti mengerjakan soal, penilaian sikap dan penilaian keaktifan siswa pada saat preses pembelajaran 


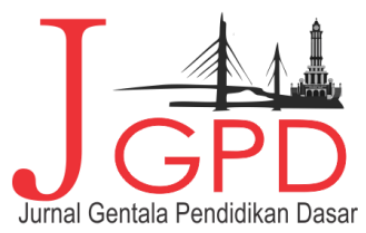

JURNAL geNTALA PENDIDIKAN DASAR Vol.3 No. I June 2018 Page 145 -162

P-ISSN : 2614-7092, E-ISSN : 2621-9611

Available Online at: http://online-journal.unja.ac.id/index.php/gentala

email : penyunting.jurnal.g-pgsd回unja.ac.id

berlangsung. Tetapi masih ada sebagian siswa yang belum mencapai sesui dengan indikator yang di harapkan guru.

Berdasarkan hasil observasi peneliti dapat peneliti simpulkan bahwa pada tahap penilaian guru memberikan tugas sesui dengan materi pembelajaran hanya saja pada tahap penilaian siswa belum tercapai sesui dengan yang guru harapkan.

Hasil wawancara peneliti dengan Ibu Neti S.Pd selaku guru kelas IV SD Negeri 13/1 Muara Bulian pada tanggal 03 Mei 2016 mengenai hasil penilaian dari hasil kerja siswa, apakah sesui dengan konsep yang Ibu rancang, mengatakan bahwa :

"Menurut saya hasil penilaian dilihat dari hasil belajar siswa cukup baik, hanya

saja masih ada sebagian siswa yang belum mencapai dengan sempurna masih

dibutuhkan proses dan bimbingan secara bertahap"

Sehingga dapat diambil kesimpulan bahwa kendala yag saya hadapi dalam melaksanakan proses pembelajaran siswa masih kurang peduli dengan nilai cinta tanah air yang ada di Indonesia.

\section{Kendala penerapan nilai cinta tanah air pada pembelajaran PKn}

Berdasarkan hasil wawancara peneliti dengan Ibu Neti S.Pd selaku guru kelas IV SD Negeri 13/1 Muara Bulian pada tanggal 03 Mei 2016 mengenai kendala Ibu dalam melaksanakan penerapan nilai cinta tanah air pada pembelajaran PKn, mengatakan bahwa :

"Adapun kendala yang saya hadapi dalam pelaksanaan pasti ada, terutama kurangnya peduli siswa dengan nilai cinta tanah air pada bangsa Indonesia, kedua kurangnya dukungan dari pihak sekolah dalam penerapan nilai cinta tanah air, karena dukungan dari sekolah sangat penting bagi siswa"

Sehingga dapat diambil kesimpulan dalam penerapan nilai cinta tanah air sekolah merupakan faktor pendukung yang sangat penting bagi siswa.

\section{Pembahasan}

Berdasarkan hasil observasi, wawancara dan dokumentasi yang dilaksanakan di sekolah SD Negeri 13/1 Muara Bulian seperti pada perencanaan, pelaksanaan, penilaian. Hal ini terlihat dari perencanaan guru merancang dan membuat Rencana Pelaksanaan Pembelajaran (RPP) yang pertama dilakukan oleh guru yakni, melihat standar kompetensi dan kompetensi dasar, kemudian 


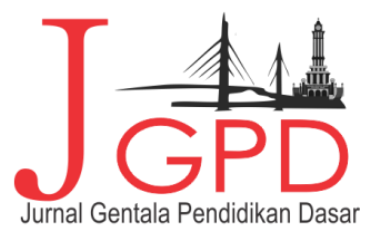

JURNAL geNTALA PENDIDIKAN DASAR Vol.3 No. I June 2018 Page 145 -162

P-ISSN : 2614-7092, E-ISSN : 2621-9611

Available Online at: http://online-journal.unja.ac.id/index.php/gentala

email : penyunting.jurnal.g-pgsd国unja.ac.id

guru merumuskan indikator pembelajaran sesuai dengan standar kompetensi dan kompetensi dasar, kemudian menentukan tujuan pembelajaran sesui dengan indikator yang telah dibuat. Pada proses pelaksanaan guru menggunakan metode ceramah dan menggunakan media gambar.

Pada pelaksanaan, guru memulai pembelajaran dengan mengajak anak berdoa, mengabsen siswa, menyanyikan lagu Indonesia raya dan mengingat pembelajaran sebelumnya. Kemudian pada proses guru meminta membuka buka halama 61, guru menjelaskan dan siswa memperhatikan. Melaksanakan proses pembelajaran sesui dengan langkah-langkah yang disusun dari tahap pembukaan, inti dan penutup.

Pada penilaian guru melakukan guru melakukan penilaian berdasarkan penilaian kerja seperti mengerjakan soal, penilaian sikap dan penilaian keaktifan siswa pada saat preses pembelajaran berlangsung. Tetapi masih ada sebagian siswa yang belum mencapai sesui dengan indikator yang di harapkan guru.

\section{KESIMPULAN DAN IMPLIKASI}

\section{Kesimpulan}

Berdasarkan hasil penelitian dan pembahasan yang dilakukan peneliti maka dapat disimpulkan bahwa penerapan nilai cinta tanah air pada pembelajaran PKn yang dilakukan oleh guru pada proses pembelajaran cukup baik berdasarkan langkah-langkah dalam pembelajaran seperti perencanaan, guru menyiapkan Rencana Pelaksanaan Pembelajara (RPP), bahan ajar dan media, pelaksanaan guru membahas materi tentang organisasi pemerintahan pusat yang meliputi presiden dan wakil presiden, menteri-menteri, dan sistem perintahan pusat. Hanya saja terdapat kendala kurangnya peduli siswa tentang nilai cinta tanah air pada bangsa Indonesia. Sedangkan pada tahap penilaian masih ada sebagian siswa yang belum mencapai indikator yang sesui guru harapkan.

\section{Implikasi}




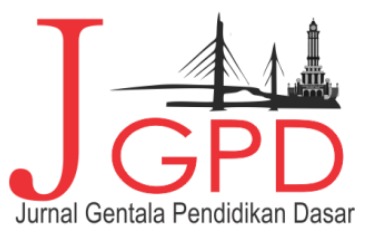

JURNAL geNTALA PENDIDIKAN DASAR Vol.3 No. I June 2018 Page 145 -162

P-ISSN : 2614-7092, E-ISSN : 2621-9611

Available Online at: http://online-journal.unja.ac.id/index.php/gentala

email : penyunting.jurnal.g-pgsd国unja.ac.id

1. Guru sebaiknya secara aktif mempelajari serta memahami lebih mendalam tentang pembelajaran PKn dan terus berupaya meningkatkan kemampuan dalam melaksanakan pembelajaran.

2. Kepada peneliti lain untuk bisa mengkaji dan meneliti ulang masalah ini, sebab hasil penelitian ini masih jauh dari kesempurnaan. Hala inin dikarenakan semata-mata keterbatasan pengetahuan, namun demikaian semoga hasil penelitian ini bisa dijadikan acuan untuk peneliti selanjutnya.

\section{DAFTAR PUSTAKA}

Ahmadi, Abu dan Munawar Sholeh. 2005. Psikologi Perkembangan. Jakarta: Rineka Cipta Ahmadi, Abu dan Widodo Supriyono. 2008. Psikologi Belajar. Jakarta : Rineka Cipta

Susanto Ahmad .2013. Teori Belajar Pembelajaran di Sekolah Dasar. Jakarta : Kencana

Supriya, Sutedejo. 2009. Pendidikan Kewarganegaraan . Jakarta : PUsat Perbukuan, Departemen Pendidikan Nasional

Daryanto, Darmiatun Suryati .2013. Pendidikan Karakter di Sekolah. Yogyakarta: Gava Media

Hamalik,Oemar. 2012. Psikologi Belajar Mengajar. Bandung:Sinar Baru Algesi.

Rusman.2014. Model-Model Pembelajaran. Jakarta.PT.Raja Grafindo Persada.

Sufri,dkk. 2012. Pembelajaran matematika di sd jambi. Unja

Arikunto, Suharsimi. 2010. Prosedur Penelitian (Suatu Pendekatan Praktik). Jakarta: Rineka Cipta

Utami. 2013 Penanaman Nilai-Nilai Cinta Tanah Air Pada Siswa Melalui Pembelajaran Pendidikan Kewarganegaraan Di Smk Negeri 1 Banyudono Kabupaten Boyolali Tahun Ajaran 2012/2013

Lestari. 2014 Penanaman nilai cinta tanah air di SD Negeri 148/1 Kilangan 1 Skripsi tidak diterbitkan, Jambi: FKIP Universitas Jambi

Darmadi, Hamid. 2011. Metode penelitian pendidikan, Bandung: Alfebeta

Dalyono. 2010. Psikologi Pendidikan. Jakarta: Rineka Cipta

Djamarah Syaful Bahri 2011. Psikologi Belajar. Jakarta : PT Rineka Cipta

Djamarah. 2008. Proses belajar mengajar.Bandung : Bumi Aksara

Susanto Ahmad 2013.Teori Belajar Pembelajaran. Jakarta : Prenadamedia Group

Syah Muhibbin. 2001. Psikologi Belajar, Logos. Wacana Ilmu, Jakarta

Silalahi, Ulber. 2009. Metode Penelitian Sosial. Bandung: Refika Aditama

S. Nasution. 1995. Didaktik Asas-asas Mengajar.Bumi Aksara, Jakarta

Sugiyono. 2012. Statiska untuk penelitian. Bandung: Alfabeta

Sugiyono. 2014. Metode Penelitian Kuantitatif, Kualitatif dan R dan D. Alfabeta Bandung

Malik Affan, dkk. 2011. Panduan Penulisan Skripsi. Jambi: Universitas Jambi 